\title{
Detection of Resistant Sources against Collar Rot of Chickpea Caused by Sclerotium rolfsii Sacc. Under Field Conditions
}

\author{
S.S. Shirsole*, N. Khare, N. Lakpale and A.S. Kotasthane \\ Department of Plant Pathology, IGKV, Raipur-492012 (C.G.), India \\ *Corresponding author
}

\begin{abstract}
A B S T R A C T
Keywords

Resistant, Collar rot, Chickpea, Genetic, Vegetative

Article Info

Accepted:

06 December 2017

Available Online:

10 January 2018

One hundred eighty five chickpea entries received from AICRP (All India Coordinated Research Project) on Chickpea, were evaluated at Raipur under field condition during the year 2016-17 to identify sources of genetic resistant against collar rot disease incited by the fungus Sclerotium rolfsii. The fungus was isolated from diseased chickpea plants collected from research farm at seedling and vegetative stage of the crop, purified and maintained on PDA for further screening process. Mass culture of the pathogen was prepared on wheat grains media and inoculated in collar zone of chickpea plant, 15 days after sowing. Out of 185 chickpea entries only 5 entries viz., GNG 2331, JG 2016-9605, IPC 2012-98, RVSSG-38 and GL 12003 exhibited moderately resistant response while, the remaining were susceptible to highly susceptible for collar rot of chickpea.
\end{abstract}

\section{Introduction}

Chickpea (Cicer arietinum L.) is India's major winter pulse crop. It is third most important grain legume in the world. India is the leading chickpea-producing country with $73.3 \%$ of the world acreage and $67.4 \%$ of the production (FAOSTAT, 2014). Various biotic and abiotic stresses affect stable and high yields of chickpea crop worldwide. Among the biotic stresses, collar rot caused by soil borne fungus Sclerotium rolfsii Sacc. is a major cause when weather conditions are conducive. Collar rot is a fast spreading and destructive disease of chickpea. It has wide host range (Aycock,
1966 and Punja, 1988) and an omnivorous soil borne fungus, parasitizing root and collar region of the plant thus, producing wilt like symptoms. Generally, the disease is severe in loamy soil regions and more prevalent in paddy - chickpea or soybean - chickpea based cropping system, when soil moisture is high and temperature is warm at the seedling stage. Affected seedlings turn yellow and die. The seedlings generally collapse and show rotting at the collar region and below. As the genetical resistance is not available in chickpea crop till now, the only practicable and cost-effective control for such a devastating soil-borne pathogen is selection of cultivars. Therefore, the present study was 
conducted to screen the chickpea entries against $S$. rolfsii for the identification of resistant sources in available genotypes.

\section{Materials and Methods}

\section{Isolation of pathogen Sclerotium rolfsii from diseased samples}

Isolation was made from the fresh diseased plant samples collected from research farm at seedling and vegetative stage of the crop. The roots of diseased plant showing symptoms were washed thoroughly with water, small pieces of infected roots were cut with the help of sterilized blade. These pieces were surface sterilized with 1:1000 mercuric chloride $\left(\mathrm{HgCl}_{2}\right)$ solution for one minute followed by three washings with sterilized distilled water to remove traces of $\mathrm{HgCl}_{2}$. The pieces were then transferred aseptically to Petri plates containing sterilized PDA and incubated at $25 \pm 2^{0} \mathrm{C}$ for three to five days and examined at frequent intervals to see the growth of the fungus developing from different pieces. As and when fungal colony appears they were transferred to PDA slant for purification of culture.

\section{Mass multiplication of Sclerotium rolfsii}

The $S$. rolfsii was mass multiplied in wheat grain media. Wheat grains were soaked in water for $6 \mathrm{hrs}$ then little boiled, drained excess water, air dried and supplemented with $50 \mathrm{~g}$ calcium carbonate in $1 \mathrm{~kg}$ wheat grains.
Two hundred gram wheat grains were filled in $6 \times 11$ inches polythene bags and plugged with non-absorbent cotton with the support of one inch diameter PVC ring (length 1.5 inch).

These bags were sterilized in autoclave with $1.02 \mathrm{~kg} / \mathrm{cm}^{2}$ pressure for $25-30$ minutes. The sterilized bags were inoculated with 2-3 mycelial discs $(5 \mathrm{~mm})$ taken from the periphery of the with 5 days old culture of $S$. rolfsii previously grown on PDA. The inoculated bags were incubated in BOD incubator at $25 \pm 2^{0} \mathrm{C}$ for 15 days. Multiplied culture of $S$. rolfsii inoculated in collar zone of chickpea plant, 15 days after sowing.

\section{Screening of chickpea entries}

Seeds were procured from AICRP (All India Coordinated Research Project) on Chickpea, Raipur. The field experiment was laid out during rabi season 2016-2017 at the research farm, IGKV Raipur.

One hundred eighty five entries were screened against $S$. rolfsii. Each test entry was sown in a plot of two rows of 5 meter length $30 \mathrm{~cm}$ apart alternating with one row of susceptible check variety L 550 after every two test entry and replicated twice.

Observations on emergence were recorded at ten and twenty DAS. Culture of $S$. rolfsii was artificially inoculated in collar zone 15 days after sowing.

Table.1 IIPR rating scale

\begin{tabular}{|l|l|l|l|}
\hline S. No. & Reaction & Per cent mortality & Score \\
\hline $\mathbf{1}$ & R- Resistant & $<10$ & 1 \\
\hline 2 & MR- Moderately Resistant & $10-20$ & 2 \\
\hline 3 & MR- Moderately Resistant & $21-30$ & 3 \\
\hline 4 & S- Susceptible & $31-40$ & 4 \\
\hline 5 & HS- Highly Susceptible & $>40$ & 5 \\
\hline
\end{tabular}


Table.2 Reaction of chickpea entries against collar rot of chickpea

\begin{tabular}{|c|c|c|c|c|}
\hline $\begin{array}{l}\text { Sr. } \\
\text { No. }\end{array}$ & $\begin{array}{l}\text { Per cent } \\
\text { mortality }\end{array}$ & $\begin{array}{l}\text { Score/ } \\
\text { reaction }\end{array}$ & Name of entries & $\begin{array}{l}\text { Total } \\
\text { entries }\end{array}$ \\
\hline 1 & Less than 10 & $1(\mathrm{R})$ & Nil & Nil \\
\hline 2 & $10-20$ & $2(\mathrm{MR})$ & Nil & Nil \\
\hline 3 & $21-30$ & 3 (MR) & $\begin{array}{l}\text { AVT } 1 \text { (LS): IPC 2012-98, RVSSG-38 and GL } 12003 \\
\text { IVT (LS): GNG } 2331 \text { and JG 2016-9605 }\end{array}$ & 5 \\
\hline 4 & $31-40$ & $4(S)$ & $\begin{array}{l}\text { AVT-1 (LS): PG 186(ch) and NDG 14-24 } \\
\text { IVT (LS): IPC 2013-33 }\end{array}$ & 3 \\
\hline 5 & Above $40 \%$ & 5 (HS) & $\begin{array}{l}\text { AVT-1 (DESI): GJG 1318, GNG 2300, DCP 92-3(ch), AKG 1109, GCP } 105 \text { (ch), JG } \\
\text { 315, H 12-26, BRC 3, GNG 2300, H 12-26, BDNG 2015-1, GJG 1320, IPC 2011-141, } \\
\text { NDG 14-11, GNG 1581(ch), H 12-1, PG 172 } \\
\text { AVT-2 (DESI): GCP 101 (ch) and Phule G 0405 } \\
\text { IVT (DESI): NDG 15-6, GL 13042, RKG 13-380, GNG 2325, PG 177, BG 3076, H12- } \\
\text { 63, CSJ 907, JG 2016-43, IPC2013-21, NBeG 738, GJG 1403, JG 2016-44, DBGV 206, } \\
\text { PG 214,AKG 1303, CSJ 866, RKG 13-75, BG 3075, NBeG 776, RG 2011-02, RVSSG } \\
\text { 42, IPC 2012-108, BRC-1, GJG 1416, Phule G 0818, GL 13001 and H 13-36 } \\
\text { AVT-1 (LS): Phule G 13110, GNG 2299, H 12-62,, H12-55, BG 372(ch), Pusa 547(ch), } \\
\text { GNG 2304,H12-62, NBeG 507, BG 3068, GNG 2299, RSG 963(ch), RKG 13-515, IPC } \\
\text { 2012-49, CSJ 884, NbeG 511, GNG 2144(ch), IPC 2012-98, NBeG 778, GNG 2304, } \\
\text { RKG 13-180 and GL 29098 } \\
\text { AVT-2(DESI LS): PG 0104, GNG 2261, PG 0109, RSG 963 (ch), BG 372 (ch), IPC } \\
\text { 2010-62, JSC 56 (RVG 203) (ch), BG 372 (ch) and GNG 2144 (ch) } \\
\text { IVT(LS): PG 178, JG 2016-45, CSJ887, GNG 2327, BG 3079, GL 14012, IPC 2010- } \\
\text { 217, H 12-29, RSG 957, RG 2011-06, RSG 963 (ch), DC 16-1, JSC 56 (RVG 203) (ch), } \\
\text { GJG 1401, GL 14002, H 13-03, PG 160, RVSSG 45,Phule G 13116 and NBEeG 778 } \\
\text { AVT (RF): NBeG 740, ICCV 10 (ch) and GJG 1316 } \\
\text { IVT (RF): IPC 2013-70, GNG 2346, BG 3078, CSJ 824, RKG 13-393, H 13-12, Phule } \\
\text { G 0802, RSG 931 (ch), AKG 1216, GNG 2340, BG 3077, GJG 1421, JG 11(ch), CSJ } \\
\text { 515 (ch), Vijay (ch), RSG 888 (ch), NBeG 779, BGD 133, H 13-15, GL 29078, Phule G } \\
\text { 0809, IPC 2010-219, RKG 13-460, NBeG 620, CSJ 882 and GAG 1423 } \\
\text { Mechanical Harvesting: H 13-09, Phule G 0914, CSJ 515 (ch), DBGV 3205, CSJ 303, } \\
\text { RKGM 1, PG 159, BG 3082, Phule G 08108, JG 2016-24, BG 3081, RVSSG 48, } \\
\text { DBGV 204, RKGM 2, RCBM 3, HC 5 (ch), NBeG 03105, DBGV 210, GL 1407, Phule } \\
\text { G 0916, CSJ 1005, BG 3062, H 12-17, IPC 2013-74 and PG 183 } \\
\text { DTIL: RVSSG 52, DIBG 205, Annegiri (ch), RKD 1, MBABC-WR-SA 2, NBeG 786, } \\
\text { DIBG 203, RVSS 51, ICCV 10 (ch), MABC-WR-SA1, NBeG 1004, DIBG 204, RKD } 4 \\
\text { and NBeG 506 }\end{array}$ & 177 \\
\hline \multicolumn{3}{|c|}{ Total entries } & \multicolumn{2}{|l|}{185} \\
\hline \multicolumn{3}{|c|}{ L.S.I. } & \multicolumn{2}{|l|}{4.92} \\
\hline
\end{tabular}

Light irrigation was given just to activate the growth of fungus. Observations on per cent mortality were started from ten days after inoculation and recorded at five day intervals upto marurity, finally computed as follows.

Total infected plant

Per cent incidence $=$

Total emergence of plant

\section{Results and Discussion}

In present study, 185 chickpea entries were screened against collar rot pathogen under field conditions. Location severity index (LSI) was high i.e. 4.92. Only 5 entries viz., GNG 2331, JG 2016-9605, IPC 2012-98, RVSSG-38 and GL 12003 were found moderately resistant to this disease, whereas, 3 entries IPC 2013-33, NDG 14-24 and PG 
186 (ch) were identified as susceptible and the remaining were highly susceptible for collar rot of chickpea. None entry was resistant to collar rot. This shows a high level of aggressiveness of the pathogen or relatively narrow diversification of genetic material under study. Gaurkhede et al., (2015) reported that in a field screening of 284 chickpea germplasm accessions against collar rot, 9 were found free from disease and 29 exhibited $<10$ per cent mortality due to collar rot (Table 2).

Gupta and Mishra,(2009) screened among 120 lines of chickpea in disease sick fields for 3 consecutive years and 32 entries performed consistent resistant reaction to collar rot. Twelve accessions were found free from collar rot during the testing years under high disease pressure. Hussain et al., (2005), screened 57 cultivars and found only one genotype highly resistant. Sugha et al., (1991) evaluated 210 chickpea lines/cultivars from different sources. None of these were resistant or even moderately resistant.

\section{References}

Aycock, R. A. 1966. Stem rot and other diseases caused by Sclerotium rolfsii. N. C. Agric. Exp. Stn. Tech. Bull. 17.
FAOSTAT (Food and Agriculture Organization of the United Nations Statistical Database), 2014. FAOSTAT Production Statistics of Crops.

Gaurkhede J., Gupta O. and Patil M. 2015. Management of collar rot of chickpea by Pseudomonas fluorescens and identification of sources of resistance. Journal of Food Legumes 28(2): 51-54.

Gupta, Om and Mishra, M. 2009. Screening of chickpea germplasm accessions for resistance to Collar rot. J. Food Legumes. 22(2):140-141.

Hussain, A., S.M. Iqbal and N. Ayub. 2005. Screening of chickpea against collar rot caused by Sclerotium rolfsii Sacc. Pakistan Journal of Agriculture, Agricultural Engineering and Veterinary Sciences, 21(1): 32-34.

Punja, Z.K. 1988. Sclerotium (Athelia) rolfsii, a pathogen of many plant species. In: Sidhu GS, ed. Genetics of plant pathogenic fungi. Vol. 6. London: Academic Press. pp. 523-534.

Sugha, S.K., Sharma B.K. and Tyagi, P.D. 1991. A modified technique for screening chickpea (Cicer arietinum) varieties against collar rot caused by Scerotium rolfsii. Indian J. Agric. Sci., 61(4): 289-290.

\section{How to cite this article:}

Shirsole, S.S., N. Khare, N. Lakpale and Kotasthane, A.S. 2018. Detection of Resistant Sources against Collar Rot of Chickpea Caused by Sclerotium rolfsii Sacc. under Field Conditions. Int.J.Curr.Microbiol.App.Sci. 7(01): 502-505. doi: https://doi.org/10.20546/ijcmas.2018.701.059 